NBER WORKING PAPER SERIES

\title{
ARE THERE THRESHOLDS OF CURRENT ACCOUNT ADJUSTMENT IN THE G7?
}

\author{
Richard H. Clarida \\ Manuela Goretti \\ Mark P. Taylor \\ Working Paper 12193 \\ http://www.nber.org/papers/w12193
NATIONAL BUREAU OF ECONOMIC RESEARCH
1050 Massachusetts Avenue
Cambridge, MA 02138
April 2006

The authors would like to thank Bob Cumby, Bruce Hansen, Martin Feldstein and participants at the July 2004 NBER pre-conference for helpful suggestions, and to thank Mike Vaknin for superb research assistance. Special thanks to Rosemary Marcuss of the Bureau of Economic Analysis for agreeing to compile and make available revised estimates of exchange rate revaluation of the US foreign asset position. Richard Clarida is the C. Lowell Harriss Professor of Economics at Columbia University and a research associate of the NBER. Manuela Goretti is a PhD candidate at the University of Warwick. Mark Taylor is Professor of Macroeconomics at the University of Warwick and a research fellow of the CEPR. The views expressed herein are those of the author(s) and do not necessarily reflect the views of the National Bureau of Economic Research.

(C2006 by Richard H. Clarida, Manuela Goretti and Mark P. Taylor. All rights reserved. Short sections of text, not to exceed two paragraphs, may be quoted without explicit permission provided that full credit, including () notice, is given to the source. 
Are There Thresholds of Current Account Adjustment in the G7?

Richard H. Clarida, Manuela Goretti and Mark P. Taylor

NBER Working Paper No. 12193

April 2006

JEL No. F320, F410

\begin{abstract}
$\underline{\text { ABSTRACT }}$
We find evidence of threshold behavior in current account adjustment for the G7 countries, such that the dynamics of adjustment towards equilibrium depend upon whether the current-account/ netoutput ratio breaches estimated, country specific current account surplus or deficit thresholds. Both the speeds of adjustment and the size of the thresholds are found to differ significantly across countries. In addition, we also find evidence of shifts in means and variances of exchange rate changes, stock returns, and interest differentials that coincide with the current account adjustment regimes identified by the model.
\end{abstract}

Richard H. Clarida

Columbia University

420 West 118th Street

Room 826, IAB

New York, NY 10027

and NBER

rhc2@ columbia.edu

Manuela Goretti

University of Wisconsin-Madison

Department of Economics

Social Studies Building - 7314

1180 Observatory Drive

Madison, Wisconsin 53706-1393

m.goretti@warwick.ac.uk

Mark P. Taylor

University of Warwick

UNITED KINGDOM

mark.taylor@warwick.ac.uk 


\section{Introduction}

The sustainability and adjustment of current account imbalances among the world's major industrialized countries is a subject that is receiving considerable attention among policymakers, financial market practitioners and academics. At more than $\$ 600$ billion and nearly 6 percent of US GDP, the US current account deficit attracts the most focus, but there are also material current account imbalances in other deficit countries such as the UK and in surplus countries such as Japan and Germany.

Some respected experts have expressed concern that current account imbalances of this magnitude and persistence indicate that the global economy is operating in a "danger zone" in which disruptive and volatile reactions in currency, bond, and equity markets are likely to result. For example, in C. Fred Bergsten (2002) has argued that "research at both the Federal Reserve Board and the Institute for International Economics reveals that industrial countries, including the United States, enter a "danger zone" of current account unsustainability when their deficits reach 4-5 percent of GDP $[\ldots]$ At these levels, corrective forces tend to arise either spontaneously from market forces or by policy action". Other observers have made a similar point, arguing that there is a "threshold" current account imbalance beyond which current account adjustment must ultimately take place, even if evidence of adjustment is scarce or non-existent before the threshold is reached. This point of view is represented clearly in a recent survey paper on this subject prepared by the Fed Reserve Bank of Kansas City (Holman (2001)):

While there is considerable uncertainty about the precise thresh- 
old [...] a current account deficit greater than 4.2 percent of GDP is unsustainable. This estimate, based on the 1980s and early 1990s, represents the average threshold at which current account deficits in several industrialized economies started to narrow after trending up for a sustained period.

Existing empirical work on this subject is suggestive but is not in fact specifically aimed at answering the question "are there thresholds of current account adjustment", or exploring its implications. Influential papers by Milesi Ferretti-Razin (1998) and Freund (2000) employ a careful and informative methodology to pull together a set of empirical regularities about how adjustments of large current account deficits have taken place in previous "episodes" which meet certain ex ante criteria. For example, in order for a current account deficit adjustment episode (called a reversal) to be included in the Freund sample, it must meet the following four criteria:

1. The current account deficit exceeded two percent of GDP before the reversal.

2. The average deficit was reduced by at least two percent of GDP over three years (from the minimum to the three-year average).

3. The maximum deficit in the five years after the reversal was not larger than the minimum deficit in the three years before the reversal.

4. The current account was reduced by at least one third.

These are very similar to the criteria introduced by Milesi-Ferretti and Razin (1998) in their study. Their motivation for focusing on the adjustment of large current account deficits that meet these criteria is explained as 
follows:

In the definition of reversal events we want to capture large and persistent improvements in the current account imbalance, that go beyond short-run current account fluctuations as a result of consumption smoothing. The underlying idea is that "large" events provide more information on determinants of reductions in current account deficits than short run fluctuations.

The work of Milesi Ferretti - Razin, Freund, and - using a somewhat different methodology Mann (2002) - has had an impact on the way that policymakers discuss current account adjustment, especially in the context of the record US deficits recorded in recent years. For example, Federal Reserve Chairman Greenspan (2003), citing Freund's work has said:

[W] hat do we know about whether the process of reining in our current account deficit will be benign to the economies of the United States and the world? According to a Federal Reserve staff study, current account deficits that emerged among developed countries since 1980 have risen as high as double-digit percentages of GDP before markets enforced a reversal. The median high has been about 5 percent of GDP.

While much can be and has been learned by studying past episodes of adjustment of large current account deficits (as defined by the criteria used by Milesi Ferretti-Razin and Freund), there remains a number of unresolved empirical questions pertaining to the modeling, estimation, and interpretation 
of the current adjustment process among the large industrialized countries. These questions include:

- Does the process of adjusting to current account deficits differ from the process of adjusting to current account surpluses? (does sign matter?)

- Does the process of adjusting to "large" current account imbalances differ from the process of adjusting to smaller current imbalances? (does size matter?)

- If so, is there a way to estimate how large is "large" and does this estimate differ from country to country? (does one size fit all?)

- Is the absence of evidence about the adjustment of a large current account imbalance evidence in favor of the sustainability of said large imbalance? (is the absence of evidence evidence of sustainability?)

It is the aim of this paper to provide an empirical framework that can be used to begin to answer questions such as these. We will argue that, for any particular country, all four of these issues are in fact intrinsically related to one another and to the specification of the econometric model which best describes that country's current account dynamics. If the current account, suitably scaled by net output (GDP net of investment and government purchases), is a linear, stationary stochastic process with a constant unconditional mean, as is often assumed in empirical work, then the answers to these four questions are straightforward: 'no', 'no', 'moot', and 'yes'.

An immediate implication of stationarity is that any current account/net output ratio not equal to the unconditional mean is unsustainable by the 
definition of a stationary stochastic process. This applies to surpluses as well as deficits. However, as an empirical matter, the dynamic process by which the current account adjusts to its unconditional mean depends crucially on whether the process is linear or nonlinear. In particular, if the process is linear, adjustment is symmetric above and below the long-run equilibrium, and the speed of adjustment is independent of the magnitude of the displacement from long-run equilibrium (the unconditional mean). For a linear, stationary current account/net output process, there is nothing to be gained by just focusing on the adjustment of current account deficits and excluding the data on adjustment to surpluses (all relative to the unconditional mean current account/net output ratio which may be either positive or negative). Moreover, there is no reason to focus on the adjustment to "large" deficits as providing different or more information than episodes of adjustment to small deficits (relative to the unconditional mean) since all episodes provide the same information. Finally, as should be obvious by now, for a linear stationary stochastic process there is no particular "threshold" beyond which markets and/or shifts in policy force a reversal and below which adjustment is absent.

By contrast, if the stationary stochastic process which governs the current account adjustment to its long mean is non-linear, then both the "sign" and "size" of the current account imbalance does matter for the adjustment process, and the size of the current account imbalance beyond which adjustment takes place may well be country specific (as alluded to by Chairman Greenspan and as is suggested by the empirical work cited above). Finally, if the stationary stochastic process is non-linear, absence of evidence of ad- 
justment of a large current account imbalance is not evidence of the absence of the ultimate adjustment of the imbalance.

There is a tractable and testable nonlinear time series model that conveniently exhibits all of the features of the current account adjustment process that have been the focus of recent discussions, and that nests as a special case the linear stationary stochastic process model for the current account that is often assumed in empirical work. It is the threshold auto regression model introduced in Tong (1978) and studied extensively by Hansen (1996,1999a, 1999b). For a stationary stochastic threshold model with mean $\mu$ and thresholds $\underline{\delta}$ and $\bar{\delta}$, there is no tendency for ca=current account/net output $-\mu$ to adjust to its mean of 0 unless it has crossed either the threshold $\underline{\delta}$ or the threshold $\bar{\delta}$. In the 'regime' with $\underline{\delta}<c a<\bar{\delta}$, deficits or surpluses (relative to $\mu$ ) persist, and there is no tendency for imbalances to revert. However, the absence of evidence of mean reversion in this regime is not evidence that deficits or surpluses relative to $\mu$ are 'sustainable' since, by stationarity, the only sustainable current account imbalance is equal to the unconditional mean.

In a threshold model, a necessary condition for adjustment to commence is for $c a$ to cross either the deficit threshold $\underline{\delta}$ or the surplus threshold $\bar{\delta}$, parameters which can be estimated from the data, not imposed ex ante. In the deficit adjustment regime, $c a<\underline{\delta}$, and $c a_{t}=\underline{\rho} c a_{t-1}+\varepsilon_{t}$. Adjustment continues until $c a$ reaches $\underline{\delta}$ at which point any further adjustment is driven by shocks to $\varepsilon_{t}$. In the surplus regime adjustment regime, $c a>\bar{\delta}$, and $c a_{t}=\bar{\rho} c a_{t-1}+\varepsilon_{t}$. Adjustment continues until $c a$ reaches $\bar{\delta}$ at which point any further adjustment is driven by shocks to $\varepsilon_{t}$. Evidently, in a threshold 
model, the sign and size of the $c a$ imbalance can matter, thresholds can differ across countries, and the absence of evidence of adjustment is not the evidence of absence of future

The plan of the paper is as follows. In Section 2 we review some basic empirical predictions of the modern workhorse model of the current account, the rational expectations, intertemporal approach model developed in Sachs (1981, 1982), estimated by Sheffrin and Woo (1989), and recently extended by Kano (2003). The basic prediction of this model, once one allows for permanent shocks to the level of net output as in Campbell and Deaton (1989), is that the ratio of the current account to net output (GDP less investment less government purchases) should be a stationary stochastic process with an unconditional mean determined by the relationship between the real interest rate and the per capita rate of growth. We also argue that a general equilibrium, two-country version of the Weil (1989) infinite horizon, overlapping generations model of the current account - a model in which the global real interest rate and the net foreign asset or liability position of each country is endogenously determined - also has the prediction that the current account to net output ratio is constant in steady state and determined by underlying parameters such as rates of time preference, the steady state rate of global growth, and the relative size of the two countries. In our paper, we will follow most of the empirical work in this area and take the stationarity of the current account to net output ratio as given. The question at the heart of the present paper is whether or not the stationary stochastic process which describes the current account to net output ratio in the G7 countries features linear or nonlinear adjustment to the unconditional mean. We conclude Sec- 
tion 2 by presenting, for each G7 country the results of a non-parametric statistical test of the null hypothesis of a linear adjustment of the current account to net output ratio against the alternative of non-linear adjustment using quarterly data for the sample 1979:1 - 2003:3. This is an application of a test for nonlinearity developed by Terasvirta (1994). For the G7 countries in our sample, we find statistically significant evidence against the null of linear adjustment of the current account to net output ratio and in favor of the alternative of nonlinear adjustment.

In Section 3 of the paper, we estimate for each G7 country a threshold autoregressive model of the current account to net output ratio, allowing for country-specific thresholds of current account surplus and deficit adjustment in each country (as suggested, for example, by Chairman Greenspan's comments), and also allowing for country specific means for the ratio of the current account to net output (as suggested, for example, by the general equilibrium version of the Weil model reviewed in Section 2). Our main findings in this section are as follows. For most of the G7 countries, we find significant evidence of threshold effects in current account adjustment. We also find that we cannot reject the null hypothesis of a random walk for the current account imbalance in each country when that ratio does not exceed (in absolute value) the country specific surplus and deficit thresholds (relative to the country specific mean) estimated for that country. For most of the G7 countries, unless the current account imbalance is 'too large' - as suggested by Milesi-Ferretti and Razin (1998) - there does not appear to be a systematic tendency for adjustment to occur. A further advantage of our approach is that we can estimate from the data how large a current im- 
balance has to be before this imbalance triggers an adjustment, and we can allow these estimated thresholds to differ across countries. In fact we find substantial cross country variation in the surplus and deficit thresholds that trigger current account adjustment in each country. We also find evidence of cross country and cross regime variation in the autoregressive dynamics estimated during adjustment regimes for each country

In Section 4, we investigate what happens to the probability distributions of nominal exchange rate changes, stock price index changes, and long term interest rate differentials during the various current account adjustment regimes that we estimate for each country in Section 3. The motivation is to determine whether or not crossing the current account adjustment threshold is itself associated with shifts in the probability distributions for exchange rates, stock prices, and interest differentials. We specifically account for - and allow for current account regime-specific shifts in - autoregressive conditional heteroscedasticity as well as for shifts in the mean by estimating generalized autoregressive conditionally heteroskedastic (GARCH) models for nominal exchange rate changes, stock prices changes, and interest differentials. We also in this section explore, for the US, whether or not the expectation of a future adjustment in the current account imbalance is associated with a present shift in the probability distribution of exchange rates, stock prices, or interest differentials. We proxy this by including in the GARCH models two dummy variables (one for deficits and one for surpluses) which represent the distance between the current account imbalance and its country-specific mean when the imbalance is between the thresholds.

In Section 5, we draw on our empirical results to take stock of the present 
US current account deficit. Our empirical results indicate that compared to other G7 countries, the US over our sample exhibited relatively wide thresholds within which current account adjustment is absent and relatively slow speeds of adjustment once these thresholds, especially the deficit threshold, are crossed. Moreover, the present US current account deficit substantially exceeds - and has for some time - our estimated thresholds of current account deficit adjustment for the US. We explore several possible explanations. The first is that the threshold model, while a useful description of current account adjustment for other G7 countries, does not apply to the US and that the present deficit of nearly 6 percent of GDP is in fact sustainable. The second explanation is that there are thresholds of current account adjustment for the US, but that adjustment has been delayed over the past several years, due to unusual circumstances that were not in evidence during the sample over which the models were estimated, 1979-2003. These circumstances could include: (i) the low level of global real interest rates (which support higher levels of investment and lower levels of saving in the US than would be the case with historically average or above average real interest rates); (ii) the more muted and less uniform decline in the dollar than occurred, for example, during the 1985 - 1987 Plaza-Louvre episode (reflecting the intervention activities of Asian central banks); (iii) the fact that the US continues to run a substantial surplus in dividends, interest, and profits on its stock of foreign assets compared with the dividends, interest, and profits that it pays out on its much larger stock of foreign liabilities; (iv) the adjustment in the net foreign liability position of the US that occurs as a result of dollar depreciation (which in 2003 offset almost 80 percent of that year's current 
account deficit). We review and evaluate these potential explanations for the absence of adjustment to date in the US current account deficit even though it has passed well beyond thresholds that would have triggered adjustments in other G7 countries.

Section 6 provides some concluding remarks.

\section{A Test for Non-Linear Current Account Adjustment}

\subsection{Theoretical Considerations}

In our empirical work, we shall be modeling the dynamics of G7 current account adjustment. However, it is important to take a stand as to exactly what it is to which G7 current account imbalances are adjusting. In this paper, we draw on the implications for long-run current account equilibrium of the workhorse intertemporal model of the current account (Sachs, 1981; Sheffrin and Woo, 1990, via Campbell, 1987). This model can be written $C A_{t}=-E_{t} \sum(1+r)^{-i} \Delta Z_{t+i}$ where $Z_{t}=Y_{t}-I_{t}-G_{t}$ is the level of net output. The intertemporal approach models have been estimated and tested many times, and their high frequency implications - that current account dynamics are fully described by the discounted sum of future changes in net output - are usually rejected. However, we argue that the intertemporal model, properly specified to allow for stationarity in long run growth rates, contains an important insight about the long run behavior of the current

account. It would seem preferable to model $\Delta \log Z_{t}=\Delta z_{t}$ as stationary. 
Following Campbell and Deaton (1989), it is straightforward to show (Kano, 2003) that the log-linear approximation of the intertemporal approach model is given by $C A_{t} / Z_{t} \approx-E_{t} \sum(1+r-g)^{-i} \Delta z_{t+i}$ where $g$ is the unconditional mean of $\Delta z_{t}$. Note that if the log difference of net output is stationary, it is the current account to net output ratio which is stationary, not simply the current account itself. This seems like a more sensible long-run equilibrium condition than to assume that the current account itself is stationary.

The intertemporal approach model is partial equilibrium and is usually studied for the special case in which $r$ is equal to the rate of time preference. However, the basic prediction of that model - that the ratio $C A / Z$ is constant in the long run - also holds in the steady state of a two-country version of Weil's (1989) infinite horizon overlapping generations model. As shown in Obstfeld and Rogoff (1994, page 188), the Weil model with discount factor $\beta$ implies that the steady state current account to net output ratio is constant and given by $C A / Z=(n+g) \theta$ where $n$ is the rate of population growth, $g$ is the rate of net output growth, and $\theta$ is the endogenous ratio of net foreign assets to net output given by the solution to $\theta[1-(1+r) \beta /(1+n)(1+g)]=$ $[(1+r) \beta-(1+g)] /(1+n)(1+g)(r-g)$. Now imagine two such economies trading goods and bonds with one another that differ in two respects: size and the discount factor. Let $\beta_{1}<\beta_{2}$ and suppose that country 2 is larger than country 1. It is easy to show that in the steady state of a two-country version of the Weil model, the $\beta_{1}$ smaller country will run a steady state current account to net output deficit and the larger more patient $\beta_{2}$ country will run a steady state current account to net output surplus. Based on these considerations, we shall assume that for each $\mathrm{G} 7$ country, the ratio $C A / Z$ is 
stationary and allow for country specific means in the $C A / Z$ ratio.

\subsection{Testing for Non-Linearities in G7 Current Account Adjustment}

This paper is an empirical study of G7 current account adjustment, based on quarterly data for the period 1979:1 to 2003:3 (the data available when we began our study in the fall of 2003). We choose our starting date to begin six years after the advent of floating exchange rates and the initial globalization of the international capital market that occurred at that time and in conjunction with the first oil shock. The data in the analysis are obtained from the International Financial Statistics Database by the IMF. All variables are seasonally adjusted and expressed in national currency. According to national account statistics, the current account variable is estimated as the sum of net exports and net primary income from abroad (NPIA); net output is obtained by subtracting Government consumption expenditure and gross fixed capital formation (investment) to GDP.

We test for non-linearity in G7 current account/net output adjustment following the non-parametric test for nonlinearity developed by Luukkonen et al. (1988) and Terasvirta (1994). These authors propose a Lagrange Multiplier test for a third-order Taylor approximation to the regression func-

tion of the form: $c a_{t}=\beta_{00}+\sum_{i=1}^{p}\left[\beta_{1 i} c a_{t-1}+\beta_{2 i} c a_{t-i} c a_{t-d}+\beta_{3 i} c a_{t-i} c a_{t-d}^{2}+\right.$ $\left.\beta_{4 i} c a_{t-i} c a_{t-d}^{3}\right]+\varepsilon_{t}$. This artificial regression allows to identify general nonlinearity through the significance of the higher-order terms. The main advantage of this type of test is that it can be carried out by simple OLS and 
that - despite being designed for smooth transition regressions - is sensitive to a wide range of non-linearities (Granger and Terasvirta, 1993), although there is reason to suspect that the power of the test may be weak against some nonlinear alternatives. The results of this test are reported in Table 1.

\section{- Insert table 1 here -}

Hence, evidence of nonlinear adjustment is indicated at the $5 \%$ significance level for France, Germany and Japan, and at the $7 \%$ level for the US.

Using the multivariate bootstrap test procedure developed by Hansen (1997), the null hypothesis of linear adjustment in all countries is rejected at the $14 \%$ level. Given the possibly poor power characteristics of these tests, therefore, we felt encouraged to investigate the estimation of nonlinear models more directly.

\section{$3 \quad$ Estimating and Testing Thresholds Models of G7 Current Account Adjustment}

In this section of the paper, we estimate and test for each G7 country a threshold autoregression model of the current-account-to-net-output ratio using the univariate approach developed in Hansen (1996). We allow for and estimate country-specific means, country and regime-specific thresholds, and country and regime specific dynamic adjustment once the current account 
has crossed either of the thresholds. Letting $c a=C A / Z-\mu$, we write the equilibrium threshold autoregressive (TAR) model as

$$
\begin{aligned}
& \mathbf{c} \mathbf{a}_{t}=\bar{\rho} \times \mathbf{1}\left\{\mathbf{c a}_{t-d}, \bar{\delta}\right\} \times \mathbf{c a _ { t - 1 }}+\underline{\rho} \times \mathbf{1}\left\{\mathbf{c a}_{t-d}, \underline{\delta}\right\} \times \mathbf{c a}_{t-1}+ \\
& +\left(\mathbf{1}-\mathbf{1}\left\{\mathbf{c a}_{t-d}, \bar{\delta}\right\}\right) \times\left(\mathbf{1}-\mathbf{1}\left\{\mathbf{c a}_{t-d}, \underline{\delta}\right\}\right) \times \mathbf{c a}_{t-1}+\mathbf{e}_{t}
\end{aligned}
$$

where $1\left\{c a_{t-d}, \bar{\delta}\right\}$ is an indicator function that takes on a value of 1 when $c a_{t-d}>\bar{\delta} \geqslant 0$ (and zero otherwise) and $1\left\{c a_{t-d}, \underline{\delta}\right\}$ is an indicator function that takes on a value of 1 when $c a_{t-d}<\underline{\delta} \leqslant 0$ (and zero otherwise). This approach postulates that the persistence of the current account imbalance in a country may depend upon whether or not the current account imbalance has crossed a surplus 'threshold' of $\bar{\delta} \geqslant 0$ or a deficit threshold of $\underline{\delta} \leqslant 0$. We note that a special case of the threshold model is the case in which $\bar{\delta}=\underline{\delta}=0$ and $\bar{\rho}=\underline{\rho}<1$ in which case it collapses to a linear stationary $\operatorname{AR}(1)$ process. We experimented with a threshold $\operatorname{TAR}(2)$ specification but found in general the second lag terms to be insignificant, and thus confine our presentation to the TAR(1) models. We also select a delay parameter $d$ of two quarters as this maximises the fit of the regression in each case.

The threshold model can potentially identify three regimes of current account adjustment: a surplus adjustment regime, a deficit adjustment regime, and an 'inertia' regime $\bar{\delta}<\mathbf{c a}_{t-2}<\underline{\delta}$ in which the current account appears to follow a random walk. In a more general smooth threshold transition autoregressive or STAR model (e.g. Taylor, Peel and Sarno, 2001), the speed of adjustment does not increase discontinuously at the threshold; rather, the 
further way is the current-account-to-GDP ratio from its long-run mean, the faster the current account imbalance adjusts. Interestingly, when we experimented with estimating smooth transmission models, we found they did not capture G7 current account dynamics in a sensible way. As we shall report next, there does in fact appear to be important, discrete threshold effects which influence current account adjustment.

Before presenting the results, we will discuss some issues involved in the estimation and testing of these model for a system comprised of the G7 countries. The ca variables for the G7 group are first demeaned, in order to allow for the existence of long-run deficit/surplus means for each country rather than a zero $c a$ balance. A non-zero mean proves to be applicable for all G7 countries, with the single exception of Italy. In particular, we detect a structural break in the German series in 1991, corresponding with the German unification and the resulting change in the country national accounts; we account for the break by allowing two different means in the current account for the pre- and post-unification periods.

The two asymmetric thresholds in the TAR model are selected jointly by minimisation of the overall sum of squared errors. The estimation method involves a double grid search over ca. Following Hansen (1997), the range for the grid search is selected a priori to contain $c a$ observations in between the 15 th $(\underline{c a})$ and the 85 th percentile $(\overline{c a})$. This reduction in the grid range is needed in order to avoid sorting too few observations in one regime for extreme values of the thresholds. As a result, the appropriate ranges are defined as $\overline{\mathbf{R}}=[\mu, \overline{c a}]$ and $\underline{\mathbf{R}}=[\mu, \underline{c a}]$, for $\bar{\delta}$ and $\underline{\delta}$ respectively.

As the minimisation process for a three-regime/ two-threshold TAR pro- 
cess is numerically intensive, we rely on the estimation methodology proposed by Hansen (1999) for multiple thresholds. This consists of a three-stage grid search, where the second-stage estimation of the two-threshold model is made conditional on the first-stage single-threshold estimate of $\delta$ (either $\bar{\delta}$ or $\underline{\delta}$ ), the third stage being used as a refinement.

Furthermore, final estimates of slope parameters and standard errors for the G7 group of countries are obtained by seemingly unrelated regression (SUR) estimation, in order to allow for potential correlation between the disturbances of the different $c a$ equations, due to common unobservable factors.

Once the thresholds have been selected, according to standard asymptotic theory, (1) is linear in the parameters. As with any simple dummy-variable regression, it can be estimated by linear methods. However, statistical inference in a TAR model bears the difficulty that the thresholds $\bar{\delta}$ and $\underline{\delta}$ may be not identified under the null hypothesis in question (Davies, 1987). In this case, the usual $\chi^{2}$ distribution needs to be replaced by an approximated empirical distribution obtained by bootstrapping the residuals (Hansen 1997). In particular, artificial observations are calibrated using the restricted estimates and are then used to obtained new estimates of the restricted and unrestricted model (for an application, see Peel and Taylor 2002). The percentage of bootstrap samples - we run 1000 replications - for which the simulated likelihood-ratio statistics exceeds the actual one forms the bootstrap approximation to the p-value of the test statistic under question.

The estimation and testing results are presented in Table 2. First the test results: when we test the null hypothesis a single threshold for all coun- 
tries versus the alternative hypothesis of two thresholds, we reject the null hypothesis in favor of the alternative. This is consistent with three regimes for each country - a surplus adjustment regime, a deficit adjustment regime, and an inertia (absence of adjustment) regime. Second, when we test the hypothesis that the current account follows a random walk inside the 'inertia' regime against the alternative that it follows a mean reverting autoregressive process inside the inertia regime (a more general formulation of the threshold model) we are unable to reject the null of a random walk inside the inertia regime. In summary, the statistical tests find evidence of non-linear current account adjustment and also identify significant thresholds beyond which current account adjustment takes place.

- Insert table 2 here -

We now discuss the parameter estimates for the threshold models estimated for each G7 country. To repeat, these estimates allow for countryspecific means, country and regime-specific thresholds, and country and regime specific autoregressive dynamics. A number of interesting results are obtained. First, as suggested by Chairman Greenspan's comment cited above, we see there is wide cross-country variation in the estimated current account deficit adjustment thresholds. For example, the estimated deficit adjustment threshold for the US is -2.18 percent of net output, while for Japan it is only -0.18 percent of net output. This means that empirically, there is no evidence from these estimates of systematic adjustment in the US current account deficit until the deficit exceeds -4.19 percent of net output 
(equal to the mean of -2.01 plus the threshold of -2.18), while for Japan, adjustment begins to take place when the surplus falls below 3.77 percent of net output (equal to the mean of 3.95 plus the deficit threshold of -0.18). We estimate a similar pattern for the other 'structural' surplus countries, France and Germany. For France, we estimate that adjustment begins to take place once the surplus falls below 0.51 percent of net output; for Germany adjustment begins to take place once the surplus falls below the mean of 6.19 before unification and 1.19 percent after unification. Second, we see that for most G7 countries, there are thresholds of adjustment to current account surpluses as well as for current account deficits. Third, we see from Table 4 substantial cross-country variation in the estimated autoregressive dynamics once countries cross their current account deficit or surplus thresholds. For deficit adjustment episodes, the estimated autoregressive coefficients range from 0.827 for Germany to 0.973 for the US. For surplus adjustment episodes, the estimated autoregressive coefficients range from 0.777 in the UK to 0.944 in Italy.

\section{- Insert table 3 here -}

In the top panel of Table 3, we compute the half life of 1,2 , and 3 percent of net output displacements of the current account imbalance from the deficit threshold. In our equilibrium threshold model the speed of adjustment to a given displacement from the deficit (or surplus) threshold is a function of the distance between the imbalances and the unconditional mean, not just to the threshold itself (as for example would be the case for a so called band threshold model). As is evident from the table, the US stands out in terms 
of the slow speed of adjustment to current account deficits, even when it is adjusting. For example, in response to a 2 percent of GDP displacement of the US current account from the estimated deficit threshold of -2.18 percent (to a deficit of -4.18 percent of net output), it takes the US nearly 10 quarters on average to close 1 percentage point of that displacement, whereas for the average G6 country (G7 minus US), it takes fewer than 5 quarters to close such a displacement. In the bottom panel of Table 3, we compute the half life of 1,2 , and 3 percent of net output displacements of the current account imbalance from the upper (surplus) threshold. As before, we estimate substantial cross-country variation in the speeds of adjustment to displacements of the current account away from the adjustment thresholds. Note that the US actually adjusts faster than the G6 average to current account surpluses.

\section{- Insert table 4 here -}

In Table 4, we present some summary statistics for the three current account regimes estimated for each G7 country. We see that the average G6 (excluding the US) country spent only roughly 25 percent of the 19792003 sample in the inertia regime and thus spent 75 percent of the sample adjusting to either current account surpluses (34 percent of the sample) or deficits (41 percent of the sample). Of course, there is cross-country variation, but the G6 country spending the maximum time in the inertia regime was Canada, which spent 48 percent of sample in the inertia regime. The US, by contrast, spent a full 63 percent of the sample in the inertia regime, and only 17 percent of the sample adjusting to current account deficits, and 20 percent of the time adjusting to current account surpluses. The bottom panel 
of Table 4 reports, for each country, the average adjustment per quarter that actually occurred during the sample (as a percentage of net output) when that country was estimated to be in a deficit adjustment regime or a surplus adjustment regime. These adjustments are measured from the peak current account imbalance reached during the adjustment episode to the level reached when the adjustment regime concludes. Thus, for the average G6 country, once current account deficits (relative to mean) peak and begin to contract, they adjust at an average rate of 0.51 percent of net output per quarter (2 percent of net output per year) until adjustment concludes with the current account imbalance crossing the deficit adjustment threshold. The table also shows that for the G6, on average, once current account surpluses peak and begin to contract, they adjust at an even faster average rate 0.62 percent of net output per quarter (2.4 percent of net output per year) until adjustment concludes with the current account imbalance crossing the surplus adjustment threshold. Evidently, adjustment of current account imbalances in the US data is much more sluggish than the G6 average, with the US current account imbalance falling by roughly 0.3 percent of net output during each quarter (1.2 percent per year) that the US is in an adjustment regime.

To summarize the results of this Section, having tested and found evidence of non-linearity in G7 current account adjustment data, we estimated for each G7 country a threshold autoregressive model which allows for asymmetric, country-specific thresholds, country specific means, and regime and country specific speeds of adjustment. We find evidence in favor of deficit as well as surplus thresholds for most countries, as well as evidence of substantial crosscountry differences in the amount of time spent in the three different regimes, 
as well as in the pace at which adjustments occur. Compared with other G7 countries, the US has large thresholds of current account adjustment, spends relatively little time in adjustment regimes, and adjusts slowly even when in those imbalance adjustment regimes. In the next section of the paper, we explore what happens to the probability distributions of exchange rates, stock prices, and interest rate differentials during current account adjustment regimes in each country.

\section{Exchange Rates, Stock Prices, and Inter- est Rates During Current Account Adjust- ment Regimes}

In this section, we investigate what happens to the probability distributions of nominal exchange rate changes, stock price index changes, and long term interest rate differentials during the various current account adjustment regimes that we estimate for each country in Section 3. The motivation is to determine whether or not crossing the current account adjustment threshold is itself associated with shifts in the probability distributions for exchange rates, stock prices, and interest differentials. We specifically account for - and

allow for current account regime specific shifts in - autoregressive conditional heteroscedasticity as well as for shifts in the mean by estimating GARCH models for nominal exchange rate changes, stock prices changes, and interest differentials. We also in this section explore, for the US, whether or not the expectation of a future adjustment in the current account imbalance is as- 
sociated with a present shift in the probability distribution exchange rates, stock prices, or interest differentials.

Switching models of exchange rates were introduced in Engel and Hamilton (1990). They hypothesized that the log difference in the nominal exchange rate is a stochastic process with a regime-specific mean and a regime specific (but constant) variance. In their model, the regimes themselves are unobservable states; the probability that the exchange rate is in a particular regime is inferred from the exchange rate data itself. Our approach is different, but similarly motivated. Having found evidence of three regimes of current adjustment for each G7 country, we estimate and test whether or not being in a current account adjustment regime is associated with shifts in the drift and variance of exchange rate changes for that country. We allow for autoregressive conditional heteroscedasticity in exchange rate changes. We estimate similar models for the log difference in stock price changes and for long term interest rate differentials, allowing for regime specific drifts and variances.

The GARCH models we estimate in this section are of the form

$$
\begin{aligned}
\Delta_{t} & =d+d 1 D U M S_{t}+d 2 D U M D_{t}+u_{t} \\
\sigma_{t}^{2} & =c+a u_{t-1}^{2}+b \sigma_{t-1}^{2}+c 1 D U M S_{t}+c 2 D U M D_{t}
\end{aligned}
$$

where $D U M D_{t}$ is a dummy variable that takes on a value of 1 when a country is in a deficit adjustment regime, $D U M S_{t}$ is a dummy variable that takes on a value of 1 when a country is in a surplus adjustment regime, $\sigma_{t}^{2}$ is the conditional variance of $u_{t}$, and $\Delta_{t}$ is the log difference in the exchange 
rate, the log difference in the equity price index, or the interest rate differential (adjusted for first order autocorrelation) observed at a monthly frequency. Thus, in each quarter in which a country is in a particular regime, there will be three observations on the monthly change in the asset price during that quarter. Because Italy and France were part of the EMS during most of the sample, the behavior of their exchange rates and interest rates reflected their EMS commitments to stabilize their exchange rates vis a vis Germany. We exclude them from the analysis of this section. Estimation is by maximum likelihood. For each country, we report the results for the (log change) in the trade weighted exchange rate, the (log change) in a broad stock market index, and the differential between each county's long term interest rate and G7 average (adjusted for first order autocorrelation). When significant, we also report the results for key bilateral exchange rates. In what follows '*, indicates significance at the 5 percent level, ${ }^{(* *}{ }^{*}$ significance at the 10 percent level, and '***' at the 15 percent level. Data sources are the IFS for long-term interest rates and Bloomberg for exchange rates and stock market indeces. The sample is monthly from 1979:2 to 2003:9 with some exceptions as noted below.

\subsection{Results}

\section{US Results}

For the US dollar index, we see that the estimated coefficient on the surplus regime dummy is positive and the estimated coefficient on the deficit regime dummy is negative (Table 5). This means that the dollar index tends 
to appreciate during US surplus adjustment regimes, and to depreciate during US deficit adjustment regimes, although the coefficients are not measured precisely. For the pound, we estimate a statistically significant shift in the probability distribution of exchange rate changes that coincides with US surplus adjustment regimes, in favor an appreciation of the dollar relative to the pound. For the Canadian dollar, we estimate a statistically significant shift in the probability distribution of exchange rate changes that coincides with US deficit adjustment regimes, in favor a depreciation of the dollar relative to the Canadian dollar. We also estimate a statistically significant rise in the volatility of the Canadian dollar exchange rate that coincides with US deficit adjustment regimes. For US equity prices, we estimate a significant (at the 12 percent level) fall in equity returns during US current account deficit adjustment regimes. We also estimate a significant rise in

equity volatility that occurs during US current account adjustment regimes. For long term interest rate differentials, we do estimate a significant increase in volatility during US current account surplus adjustment regimes.

\section{JAPANESE RESULTS}

For the Yen index, we see that the estimated coefficient on the Japan current account surplus adjustment regime dummy is positive and significant, indicating that the Yen index tends to appreciate during Japan's current account surplus adjustment regimes (Table 6). For the Dollar-Yen exchange rate, we estimate a statistically significant increase in exchange rate volatility during both Japan surplus adjustment regimes and Japan deficit adjustment regimes. We also obtain point estimates that suggest that the yen tends 
to appreciate relative to the dollar during Japanese current account surplus regimes and to depreciate during Japanese current account deficit adjustment regimes, although these coefficients are not measured precisely. For Japanese equity prices, we estimate a significant fall in equity volatility during Japan current account deficit adjustment regimes. For long term interest rate differentials, we do estimate a significant increase in volatility during both Japan's current account surplus adjustment regimes and current account deficit adjustment regimes. We also estimate a significant widening in Japanese long term interest differential (it becomes larger in absolute value) during Japan's current account surplus adjustment regimes, as well as a widening during Japan's current account deficit adjustment regimes (although the latter is not significant).

\section{German Results}

For the volatility of the DM index through 1998:12, we see that the estimated coefficient on the German current account deficit adjustment regime dummy is positive and significant (Table 7). For the Dollar-DM exchange rate estimated through 1998:12, we estimate a statistically significant depreciation of the DM during German current account deficit adjustment regimes. For German equity prices, we estimate a significant fall in equity volatility during German current account deficit adjustment regimes. For long- term interest rate differentials, we do estimate a significant increase in volatility during German current account deficit adjustment regimes. German interest rate differentials increase in absolute value during deficit adjustment regimes in before unification, and narrow after unification. We split the sample at 
unification because of an obvious shift in the mean of the interest differential series at that time.

\section{UK AND CANAdian Results}

For the Canadian dollar index, we see that the estimated coefficient on the Canadian current account deficit adjustment regime dummy is negative and significant, indicating that the CAD index tends to depreciate during Canada's current account deficit adjustment regimes (Table 8). For the US Dollar-Canada exchange rate, we estimate a similar result but it is not statistically significant. For the UK, the most noteworthy result is a significant increase in equity returns during current account surplus adjustment regimes, a fall in equity volatility during UK current account surplus adjustment regimes, and a rise in equity volatility during UK current account deficit adjustment regimes (Table 9). Because of a break in the UK equity price data series at 1984:1, the UK equity sample is 1984:1 - 2003:9.

\section{Summary of Results for Subsection 4.1}

In this subsection, we have reported evidence of statistically significant shifts in the mean and variance of the probability distribution of several G7 exchange rates, equity prices, and interest rate differentials that occur in conjunction the current account adjustment regimes estimated in section 3 . Our approach cannot answer the question of which triggers what, but we do find evidence that regimes of current account adjustment do coincide with shifts in the distribution of some important asset prices. The estimates that 
are significant tend to show exchange rate depreciation during current account deficit regimes and exchange rate appreciation during current account surplus regimes. We also find statistically significant increases in exchange rate volatility during current account deficit adjustment regimes for the US, Japan, and Germany. For equity markets, we estimate that current account deficit adjustment regimes are associated with significantly lower US equity returns and higher US equity volatility, while in the UK, equity returns are higher during current account surplus adjust regimes, equity volatility is lower, while UK equity volatility is higher during current account deficit adjustment regimes.

- Insert tables 5-9 here -

\subsection{Do Expectations of Future US Current Account Adjustment Trigger Adjustment in Present Asset Prices?}

We now explore, for the US, whether or not the expectation of a future adjustment in the current account imbalance is associated with a present shift in the probability distribution exchange rates, stock prices, or interest differentials. As discussed previously, compared with other G7 countries, the US has wide thresholds of current account adjustment, spends relatively little time in adjustment regimes, and - as shown in Table 4 - adjusts slowly even when in deficit or surplus adjustment regimes. To capture the hypothesis that expectations of future current account adjustment may have an 
impact on present asset prices, we augment our basic GARCH specification to include two additional dummy variables. Let $D U M B D$ equal one when $-2.18<c a<-1$ and let $D U M B S$ equal one when $1<c a<2.15$. Thus $D U M B D$ equals one when the current account deficit is more than one percentage point below its mean but still less (in absolute value) than the deficit threshold, while $D U M B D$ equals one when the current account is more than one percentage point above its mean but still less (in absolute value) than the surplus threshold. Our specification becomes

$$
\begin{aligned}
\Delta_{t} & =d+d 1 D U M S_{t}+d 2 D U M D_{t}+d 3 D U M B S_{t}+d 4 D U M B D_{t}+u_{t} \\
\sigma_{t}^{2} & =c+a u_{t-1}^{2}+b \sigma_{t-1}^{2}+c 1 D U M S_{t}+c 2 D U M D_{t}+c 3 D U M B S_{t}+c 4 D U M B D_{t}
\end{aligned}
$$

In order to focus on significant results, we proceed in two steps. In the first step, we estimate specification (3). In the second step, we drop any dummy variable that in the first stage estimate is not significant at the 15 percent level or better. The results are reported in Table 10.

\section{- Insert table 10 here -}

From Table 10, we see that when current account deficits are large but before the US enters a current account deficit adjustment regime, the dollar index starts to depreciate, at a pace of roughly 7 percent per year. We also see that the volatility of the dollar index is lower when deficits are small but before the US enters a current account surplus adjustment regime. As for 
equity prices, the results reported in Table 5 are robust to the inclusion of the two additional dummy variables. We continue to find a significant negative effect of current account deficit adjustment regimes on equity returns, and a significant positive effect on equity volatility. Interestingly, we also find that equity volatility is lower when deficits are small but before they have entered a current account surplus adjustment regime. Finally, we see that long-term interest differentials in favor of the US are larger when current account deficits are small.

\section{$5 \quad$ Assessing the Present US Current Account Deficit}

In this section we draw on our empirical results to take stock of the present US current account deficit. Our empirical results indicate that compared to other G7 countries, the US over our sample exhibited relatively wide thresholds within which current account adjustment is absent and relatively slow speeds of adjustment once these thresholds, especially the deficit threshold,

are crossed. Moreover, the present US current account deficit substantially exceeds - and has for some time - our estimated thresholds of current account deficit adjustment for the US. We explore several possible explanations. The first is that the threshold model, while a useful description of current account adjustment for other G7 countries, does not apply to the US and that the present deficit of nearly 6 percent of GDP is in fact sustainable. The second explanation is that there are thresholds of current account adjustment for 
the US, but that adjustment has been delayed over the past several years, due to unusual circumstances that were not in evidence during the sample over which the models were estimated, 1979-2003. These circumstances could include: (i) the low level of global real interest rates (which support higher levels of investment and lower levels of saving in the US than would be the case with historically average or above average real interest rates); (ii) the more muted and less uniform decline in the dollar than occurred, for example during the 1985 - 1987 Plaza-Louvre episode (reflecting the intervention activities of Asian central banks); (iii) the fact that the US continues to run a substantial surplus in dividends, interest, and profits on its stock of foreign assets compared with the dividends, interest, and profits that is pays out on its much larger stock of foreign liabilities; (iv) the adjustment in the net foreign liability position of the US that occurs as a result of dollar depreciation (which in 2003 offset almost 80 percent of that years current account deficit). We review and evaluate these potential explanations for the absence of adjustment to date in the US current account deficit even though it has passed well beyond the thresholds that would have triggered adjustments in other G7 countries. We begin by reviewing the data on the US net foreign liability position.

Almost all claims held by foreigners against the US are dollar denominated, while US claims against the rest of the world are denominated in foreign currency. Thus, as has been emphasized by Pierre Olivier Gourinchas and Helene Rey, a real depreciation of the dollar, by increasing the real value of US holdings of foreign assets relative to foreign holdings of US assets (which of course are dollar denominated liabilities of the US) is an impor- 
tant channel of international adjustment, over and above the impact of said real depreciation on the trade balance. This channel operates by narrowing the gap between the market value of foreign claims against the US and the market value of US claims against the rest of the world. In effect, because of the willingness on the part of the rest of the world to lend to the US in the form of dollar denominated debt and equity instruments, there is a transfer of wealth to the US from the rest of the world as result of a real depreciation of the dollar, all other things - including other asset prices - equal, a qualification to which I return below. It is important to note that while the US benefits from this 'transfer' effect which increases the real value of US assets relative to US liabilities, there is of course another implication of real dollar depreciation which is the terms of trade deterioration that results from it. This terms of trade deterioration lowers the real purchasing power of any given flow of US income, and it increases the relative price of imported inputs to US based production. In addition, as Obstfeld and Rogoff have emphasized, moving toward current account sustainability requires that resources be shifted from non tradable to tradable production. Empirically, this channel of international adjustment is potentially quite important in complementing the traditional channel in which the factors that contribute to a narrowing of the current account deficit also result in a real depreciation of the dollar.

Every year, the US Commerce Department reports data on the net foreign liability position of the US, and it provides detail on the revaluation of US assets and liabilities that occurs as a result of exchange rate movements, as well as asset price changes. The data on net foreign assets and liabilities is 
subject to substantial revisions. However, until quite recently - April 2005 - the Commerce Department did not go back and revise the exchange rate and asset price revaluation attributions to make them consistent with the revised data on foreign assets and liabilities. However, at the request of one of the authors of this paper, the Commerce Department has now revised the exchange rate and asset price revaluation attributions to make them consistent with the revised data on foreign assets and liabilities. The newly released data are reported in Table 11 and they tell an interesting story.

- Insert table 11 here -

We begin with the most recent data available as of the time of writing, for year end 2003. The US began 2003 with gross foreign assets of $\$ 6.6$ trillion and gross foreign liabilities of $\$ 9.2$, for a stock of net foreign liabilities of $\$ 2.6$ trillion. During that year the US ran a current account deficit of $\$ 530$ billion which, after adjustment for errors and omissions, resulted in a net capital inflow of $\$ 546$ billion. In a simple textbook model which abstracts from asset price or exchange rate changes, this should have resulted in a dollar-for-dollar increase in net foreign liabilities, to approximately $\$ 3.1$ trillion. During that year, asset price changes in local currency terms were substantial, but they roughly canceled out, having a minimal impact on the net foreign liabilities of the US. By contrast, the exchange rate valuation effects were substantial. Dollar depreciation that year increased the value of US assets abroad by $\$ 398$ billion. By year end 2003, the net foreign liabilities of the US were valued at $\$ 2.7$ trillion dollars, an increase of only $\$ 100$ billion compared with the previously discussed US capital inflow of $\$ 545$ billion. 
Of course, a real dollar depreciation has a one-off impact on the value of US net foreign assets, and a stabilization of net foreign liabilities as a ratio of US GDP will require a reduction in the ratio of the current account to GDP. However, the current account deficit to GDP ratio need not return to zero for sustainability to be achieved. Indeed, a US current account deficit to GDP ratio in the range of 2 to 3 percent is probably consistent with sustainability at something like the global level of interest rates and equity valuations. Consider this fact: in 2001, US net foreign liabilities were 22.8 percent of US nominal GDP. Two years later, US net foreign liabilities to GDP had risen by a very modest 1.3 percentage points, to 24.1 percent of GDP, notwithstanding current account deficits of roughly 5 percent of GDP in each of 2002 and 2003. The data in Table 11 show that exchange rate valuation effects have been important in previous years. For example, in 2002, the exchange rate revaluation of US foreign assets offset 40 percent of the foreign capital inflow; in 1994 and 1995, the exchange rate valuation effect offset $52 \%$ of the net capital inflow. Of course, exchange rate appreciation has the opposite effect. Of the $\$ 1.3$ trillion rise in US net foreign liabilities that accumulated in the three years 1999-2001, $\$ 540$ billion , or 41 percent, was due to the valuation impact of the appreciation of the dollar that occurred during those years.

Another factor that should be considered when thinking about sustainability and adjustment of international imbalances is the longstanding evidence for the US of substantial differences in the rates of return that US investors earn on their foreign investments compared with the rate of return that foreign investors earn and require on their investments in the US. That 
is, even though the US is, and has been for many years, the world's largest 'net debtor', with net foreign liabilities estimated to be some $\$ 2.7$ trillion dollars at year end 2003, the US still to this day earns more interest and dividends on its foreign assets than it pays out on its foreign liabilities, even though the latter exceed the former by nearly 3 trillion dollars. Specifically, for 2004, income receipts on US assets abroad totaled $\$ 368$ billion while income payments on foreign assets in the US totaled $\$ 344$ billion. How can the US continue to run a surplus on international investment income with its large stock of international liabilities? Differences in portfolio composition can probably account for some of this. For example, in recent years 60 percent of US assets abroad were invested in foreign equities and foreign direct investment. By contrast, only 40 percent of foreign claims against the US were invested in US equities and direct investment. However, in order to account for the persistent surplus in the US international investment income account, portfolio composition is probably not sufficient. In addition, it is likely the case that the US earns consistent higher returns on its FDI than the rest of the world earns on its US FDI.

We see that in both 2003 and 2004, the US earned high returns on FDI, earning profits of 8.7 percent of FDI assets at market value in 2004 and 9.2 percent of FDI assets at market value in 2003. By contrast, foreign owned direct investment assets in the US earned 4.3 percent of assets at market value in 2004 and 3.4 percent of assets at market value in 2003. This disparity is not a recent phenomenon. As the Table shows, the US has consistently since 1989 - the year the US net foreign asset position turned negative - earned higher returns on its FDI assets than foreigners have earned on their US 
investments. The Table also reports the rate of return on non-FDI assets and liabilities. The absolute return differentials are much smaller, and are consistently negative, indicating that foreign non-FDI holdings pay slightly higher returns than US non-FDI holdings. Once we take into account the differences in portfolio composition between US assets abroad and foreign assets in the US (reported in Table 12), we obtain the time series on the total return differential reported in Table 11.

- Insert table 12 here -

Another factor that may have delayed adjustment in the US current account is the more modest decline in the broad, real trade weighted dollar as compared with the decline in the dollar that occurred during the 1985-1988. The Federal Reserve's real broad trade weighted dollar index is plotted in Figure 1.

- Insert Figure 1 here -

In the three years after the dollar's peak in early 1985, the broad dollar index declined by 30 percent. By contrast, in the three years since the dollar's recent peak in early 2002, it has declined by less than 15 percent. Obviously, the intervention by Asian central banks has limited the depreciation of the dollar against a number of significant US trading partners.

Our final point is that the US current account deficit is in part an endogenous, general equilibrium outcome of global financial and macroeconomic integration. As such, we believe it reflects a global excess supply of saving 
relative profitable investment opportunities. In a world in which there is a global excess supply of saving relative to investment, we would expect to find and indeed find today that global real interest rates are low and that some country or group of countries must absorb the surplus of internationally mobile capital. Required real rates return - as measured by yields on TIPS in the US and indexed gilts in the UK - are unusually low (below 2 percent as of this writing). In the late $90 \mathrm{~s}$, the opposite was the case and rapid (in retrospect unsustainable) world investment rates surged ahead of savings, pushing up real interest rates (Tips yields were at 4 percent in March 2000 when the bubble peaked). Although no one can say for sure how long the present imbalance between global saving and investment will persist, it seems clear that this global imbalance between saving and investment is contributing to the size of the US current account deficit and its failure to adjust as May 2005.

- Insert table 13 here -

\section{Conclusion}

Are there thresholds of current account adjustment? This paper has reported evidence in favour of this proposition. We found statistically significant evidence of differing adjustment dynamics in the current-account-to-net-output ratio for all of the G7 countries examined. In particular, each country displayed three regimes — a surplus regime and a deficit regime in which the 
current account tended to revert towards its long-run mean, albeit at different speeds in each regime (showing that sign does indeed matter), and an 'inertia regime' in which, for intermediate levels of the current account balance between the surplus and deficit regimes, current account adjustment was negligible (showing that size also matters). We also showed, however, that one size does not fit all in the sense that we found significant cross-country variation in the size of the estimated thresholds. We also found substantial cross-country variation in the estimated speed of adjustment once countries cross their current account deficit or surplus thresholds.

Our results support the findings of Caroline Freund and Frank Warnock, by providing econometric evidence on the nonlinearities and differences in current account adjustment across industrial countries. In line with their results, countries with large deficits such as the US exhibit relatively wide thresholds within which current account adjustment is absent and relatively slow speeds of adjustment once these thresholds, especially the deficit threshold, are crossed. While our analysis focuses on the relatively homogeneous post Bretton-Woods period, Barry Eichengreen and Muge Adalet present an historical analysis of current account reversals starting from the gold standard period and find evidence of substantial differences in current account adjustments episodes also across time.

We also found evidence of statistically significant shifts in the mean and variance found evidence of statistically significant shifts in the mean and variance of the probability distribution of several G7 exchange rates, equity prices, and interest rate differentials that occur in conjunction with our estimated current account adjustment regimes. In particular, we found 
a tendency towards exchange rate depreciation during current account deficit regimes and exchange rate appreciation during current account surplus regimes, and statistically significant increases in exchange rate volatility during current account deficit adjustment regimes for the US, Japan, and Germany. This suggests that a multivariate approach involving the joint modeling of exchange rates and the current account within a nonlinear framework would be a fruitful exercise, as well as being consistent with substantial evidence in favor of nonlinear adjustment in real exchange rates (see, e.g., Obstfeld and Taylor (1998); Taylor and Taylor, 2004). This is an avenue we intend to pursue in future research. 


\section{References}

[1] Adalet, M. and B. Eichengreen (2005). Current Account Reversals: Always a Problem? In 'G7 Current Account Imbalances: Sustainability and Adjustment', Richard Clarida, Editor, The University of Chicago Press.

[2] Bergsten, C. F. (2002). The Dollar and the US Economy. Testimony before the Committee on Banking, Housing and Urban Affairs, United States Senate, Washington, DC, May 1, 2002.

[3] Campbell, J. Y. (1987). Does Saving Anticipate Declining Labor Income? An Alternative Test of the Permanent Income Hypothesis. Econometrica 55(6): 1249-73.

[4] Campbell, J. Y. and R. Shiller (1987). Cointegration and Tests of Present Value Models. Journal of Political Economy 95: 1062-88.

[5] Campbell, J., and A. Deaton (1989). Why is Consumption so Smooth?. Review of Economic Studies 56: pp.357-374.

[6] Davies, R.B. (1987). Hypothesis Testing When a Nuisance Parameter Is Present Only under the Alternative. Biometrika 64: pp. 33-43

[7] Engel, C. and J. D. Hamilton (1990). Long Swings in the Dollar: Are They in the Data and Do Markets Know It? American Economic Review 80(4): pp. 689-713. 
[8] Freund, C. L. (2000). Current account adjustment in industrialized countries. Board of Governors of the Federal Reserve System. International Finance Discussion Papers 692.

[9] Freund, C. and F. Warnock (2005). Current Account Deficits in Industrial Countries: The Bigger They Are, The Harder They Fall? In 'G7 Current Account Imbalances: Sustainability and Adjustment', Richard Clarida, Editor, The University of Chicago Press.

[10] Gourinchas, P.O. and H. Rey (2005). From World Banker to World Venture Capitalist: The US External Adjustment and The Exorbitant Privilege. In 'G7 Current Account Imbalances: Sustainability and Adjustment', Richard Clarida, Editor, The University of Chicago Press.

[11] Granger, C.J. and T. Terasvirta (1993). Modelling Nonlinear Economic Relationships. Oxford University Press, UK.

[12] Greenspan, A. (2003). The evolving international payments imbalance of the United States and its effect on Europe and the rest of the world. Remarks at the 21st Annual Monetary Conference, Washington, DC, 20 November 2003.

[13] Hansen, B. E. (1996). Inference When a Nuisance Parameter Is Not Identified under the Null Hypothesis. Econometrica 64(2): pp. 413-30.

[14] Hansen, B. E. (1997). Inference in TAR models, Studies in Nonlinear Dynamics and Econometrics, 2: pp.1-14. 
[15] Hansen, B. E. (1999a). Threshold Effects in Non-dynamic Panels: Estimation, Testing, and Inference. Journal of Econometrics v93(n2): pp. $345-68$.

[16] Hansen, B. E. (1999b). Testing for Linearity. Journal of Economic Surveys v13(n5): 551-76.

[17] Holman, J.A. (2001). Is The Large U.S. Current Account Deficit Sustainable? Economic Review. Federal Reserve Bank of Kansas City. First Quarter.

[18] Kano, T. (2003). A Structural VAR Approach to the Intertemporal Model of the Current Account. Working Paper, Bank of Canada 2003-42.

[19] Luukkonen, R., Saikkonen, P., and Terasvirta, T. (1988). Testing Linearity against Smooth Transition Autoregressive Models, Biometrika, 75, pp. 491-499.

[20] Mann, C.L. (2002). Perspectives on the U.S. Current Account Deficit and Sustainability. Journal of Economic Perspectives. vol. 16(3), pp. $131-152$.

[21] Milesi-Ferretti, G. M. and A. Razin (1998). Current Account Reversals and Currency Crises: Empirical Regularities. NBER working paper 6620.

[22] Obstfeld, M. and K. Rogoff (1994). Foundations of International Macroeconomics. Cambridge, MA: MIT Press. 
[23] Obstfeld, M. and A. M. Taylor (1997). Nonlinear Aspects of GoodsMarket Arbitrage and Adjustment: Heckscher's Commodity Points Revisited. Journal of the Japanese and International Economies 11(4): 441-479.

[24] Peel, D.A. and M.P. Taylor (2002). Covered Interest Rate Arbitrage in the Inter-War Period and the Keynes-Einzig Conjecture. Journal of Money, Credit and Banking, 34: pp. 51-75.

[25] Sachs, J. D. (1981). The Current Account and Macroeconomic Adjustment in the 1970s. Brookings Papers on Economic Activity 1: pp. 201-68.

[26] Sachs, J. D. (1982). The Current Account in the Macroeconomic Adjustment Process. Scandinavian Journal of Economics 84: pp. 147-159.

[27] Sheffrin, S. M. and W. T. Woo (1990). Present Value Tests of an Intertemporal Model of the Current Account. Journal of International Economics 29(3-4): 237-53.

[28] Taylor, A.M. and M.P. Taylor (2004). The Purchasing Power Parity Debate. Journal of Economic Perspectives 18-4: pp. 135-58.

[29] Taylor, M. P., D. A. Peel, and L. Sarno (2001). Nonlinear MeanReversion in Real Exchange Rates: Toward a Solution to the Purchasing Power Parity Puzzles. International Economic Review 42(4): 1015-42.

[30] Terasvirta, T. (1994). Specification, estimation, and evaluation of smooth transition autoregressive models. Journal of the American Statistical Association 89: pp. 208-218. 
[31] Terasvirta, T. (1998). Modelling economic relationships with smooth transition regressions. In Handbook of Applied Economic Statistics; Marcel Dekker: New York, pp. 507-552.

[32] Tong, H. (1978). On a threshold model. Pattern recognition and signal processing. C. H. Chen. Amsterdam, Sijthoff and Noordhoff.

[33] Weil, P. (1989). Overlapping families of infinitely-lived agents. Journal of Public Economics 38, 183-198. 
Table 1

\begin{tabular}{|c|c|}
\hline Country & Terasvirta Linearity Tests: \\
\hline CAN & Marginal significance level 0.369 \\
\hline FRA & Marginal significance level 0.029 \\
\hline GER & Marginal significance level 0.035 \\
\hline ITA & Marginal significance level 0.136 \\
\hline JAP & Marginal significance level 0.027 \\
\hline UK & Marginal significance level 0.184 \\
\hline US & Marginal significance level 0.069 \\
\hline
\end{tabular}


Table 2

Threshold models of de-meaned CA/NO

\begin{tabular}{|c|c|c|c|c|c|c|c|}
\hline \multirow{2}{*}{$\begin{array}{c}\text { CA/NO } \\
\text { Q1 1979- Q3 } 2003 \\
\text { COUNTRY } \\
\end{array}$} & \multicolumn{2}{|c|}{ Thresholds (asymmetric band) } & \multicolumn{3}{|c|}{$\begin{array}{c}\text { Slope coefficients (estimation } \\
\text { by SUR) }\end{array}$} & \multicolumn{2}{|c|}{ Means } \\
\hline & Upper threshold & Lower threshold & above & band & below & 'Surplus' & 'Deficit' \\
\hline CANADA & 1.41 & -4.05 & $\begin{array}{c}0.927 \\
(0.048)\end{array}$ & 1.000 & $\begin{array}{c}0.930 \\
(0.060)\end{array}$ & & -1.792 \\
\hline FRANCE & 2.13 & -1.13 & $\begin{array}{c}0.931 \\
(0.048)\end{array}$ & 1.000 & $\begin{array}{c}0.910 \\
(0.045)\end{array}$ & 1.646 & \\
\hline GERMANY & 2.84 & 0.00 & $\begin{array}{c}0.880 \\
(0.070)\end{array}$ & 1.000 & $\begin{array}{l}0.827 \\
(0.064)\end{array}$ & $\begin{array}{l}6.185 \\
1.496\end{array}$ & $\begin{array}{r}\text { Pre-1991 } \\
\text { Post-1991 }\end{array}$ \\
\hline ITALY & 0.00 & -0.37 & $\begin{array}{c}0.944 \\
(0.058)\end{array}$ & 1.000 & $\begin{array}{l}0.867 \\
(0.059)\end{array}$ & & -0.269 \\
\hline JAPAN & 0.84 & -0.18 & $\begin{array}{c}0.908 \\
(0.058)\end{array}$ & 1.000 & $\begin{array}{c}0.894 \\
(0.037)\end{array}$ & 3.951 & \\
\hline UK & 1.08 & 0.00 & $\begin{array}{c}0.777 \\
(0.073)\end{array}$ & 1.000 & $\begin{array}{c}0.929 \\
(0.064)\end{array}$ & & -1.764 \\
\hline US & 2.15 & -2.18 & $\begin{array}{c}0.907 \\
(0.039)\end{array}$ & $\begin{array}{l}1.000 \\
\text { in bracke }\end{array}$ & $\begin{array}{c}0.973 \\
(0.034)\end{array}$ & & -2.011 \\
\hline Bootstrap: & $\begin{array}{l}\text { LR-test for band } \\
L R \text {-test for single }\end{array}$ & $\begin{array}{l}\text { fficient equal to } \\
\text { eshold (SUR): } r\end{array}$ & $\begin{array}{l}\text { (SUR): } m \\
\text { rg. signif. }\end{array}$ & signif. 1 & $\mathrm{el}=0.520$ & & \\
\hline
\end{tabular}




\section{Table 3}

HALF LIFE OF DISPLACEMENT FROM DEFICIT THRESHOLD (IN QUARTERS)

$\begin{array}{rrr}1 \text { percent } & 2 \text { percent } & 3 \text { percent } \\ & & \\ 1.14 & 2.49 & 3.30 \\ 2.84 & 4.08 & 4.79 \\ 3.65 & 3.64 & 3.64 \\ 3.18 & 3.84 & 4.13 \\ 4.79 & 5.48 & 5.69 \\ 9.41 & 9.41 & 9.41 \\ 4.17 & 4.82 & 5.16 \\ 6.25 & 9.99 & 12.49\end{array}$

HALF LIFE OF DISPLACEMENT FROM SURPLUS THRESHOLD (IN QUARTERS)

$\begin{array}{lrrr}\text { Canada } & 3.07 & 4.58 & 5.48 \\ \text { France } & 2.43 & 3.88 & 4.84 \\ \text { Germany } & 1.09 & 1.81 & 2.32 \\ \text { Italy } & 12.03 & 12.03 & 12.03 \\ \text { Japan } & 3.29 & 4.50 & 5.13 \\ \text { UK } & 1.09 & 1.56 & 1.82 \\ \text { G6 Avg } & 3.83 & 4.72 & 5.27 \\ \text { Us } & 1.77 & 2.82 & 3.53\end{array}$


Table 4

PERCENT OF SAMPLE SPENT IN EACH REGIME

$\begin{array}{lcccccccc} & \text { CANADA } & \text { FRANCE GERMANY } & \text { ITALY } & \text { JAPAN } & \text { UK } & \text { G6 AVG } & \text { US } \\ \text { SURPLUS } & 34 & 23 & 20 & 51 & 36 & 37 & 34 & 20 \\ \text { INERTIA } & 48 & 35 & 20 & 3 & 30 & 17 & 25 & 63 \\ \text { DEFICIT } & 18 & 42 & 60 & 46 & 34 & 46 & 41 & 17\end{array}$

ADJUSTMENT PER QUARTER DURING ADJUSTMENT REGIMES

(Measured from peak and as percent of net output)

CANADA FRANCE GERMANY ITALY JAPAN UK G6 AVG US

$\begin{array}{lllllllll}\text { SURPLUS } & 0.687 & 0.507 & 1.081 & 0.467 & 0.336 & 0.644 & 0.620333 & 0.303\end{array}$

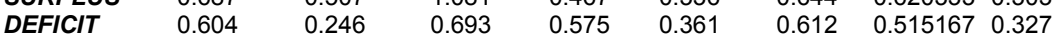




\section{Table 5}

\section{Asset Prices During US Current Account Adjustment Regimes}

$$
\begin{aligned}
& \text { US Dollar Index } \\
& \Delta_{t}=-.0004+\underset{(.0028)}{.0035 D D^{2}}-.0028 D U M D_{t}+u_{t} \\
& \sigma_{t}^{2}=.0001-.0325 u_{t-1}^{2}+.5976 \sigma_{t-1}^{2}+.00002 D U M S_{t}-.00002 D U M D_{t} \\
& \text { Pound per Dollar } \\
& \text { (.00003) (.00003) } \\
& \Delta_{t}=-.0013+.0101 D U M S_{t}-.0019 D U M D_{t}+u_{t} \\
& (.0044) * \quad(.0038) \\
& \sigma_{t}^{2}=.0002+.2151 u_{t-1}^{2}+.6013 \sigma_{t-1}^{2}+.0001 D U M S_{t}-.00002 D U M D_{t} \\
& \text { (.0001) (.00007) } \\
& \text { Canadian Dollars per US Dollar } \\
& \Delta_{t}=.0009+.0006 \text { DUMS }_{t}-.0044 D U M D_{t}+u_{t} \\
& \text { (.0019) } \quad(.0025) * * \\
& \sigma_{t}^{2}=.0002-.0161 u_{t-1}^{2}-.5754 \sigma_{t-1}^{2}+.00001 D U M S_{t}+.0002 D U M D_{t} \\
& \text { (.0001) (.00007)* } \\
& \begin{array}{cc}
\Delta_{t}=.0107-.0029 D U M S_{t}- & .0139 D U M D_{t}+u_{t} \\
(.0061) & (.0091) * * *
\end{array} \\
& \sigma_{t}^{2}=.0014+.0004 u_{t-1}^{2}+.0681 \sigma_{t-1}^{2}+.00027 D U M S_{t}+.00223 D U M D_{t} \\
& \text { (.0004) } \quad(.0011)^{*} \\
& \Delta_{t}=.0094-.0154 D U M S_{t}-.0014 D U M D_{t}+u_{t} \\
& \text { (.0304) (.0181) } \\
& \sigma_{t}^{2}=.0002-.0177 u_{t-1}^{2}+.9788 \sigma_{t-1}^{2}+.00305 D U M S_{t}+.00007 D U M D_{t} \\
& (.0009) * \quad(.00014)
\end{aligned}
$$




\section{Table 6}

\section{Asset Prices During Japan Current Account Adjustment Regimes}

$$
\begin{aligned}
& \text { Yen Index } \\
& \Delta_{t}=-.0016+.0093 D U M S_{t}+.0005 D U M D_{t}+u_{t} \\
& (.0034) * \quad(.0031) \\
& \sigma^{2}{ }_{t}=.0006-.2115 u_{t-1}^{2}-.2848 \sigma_{t-1}^{2}+.00012 D U M S_{t}-.00005 D U M D_{t} \\
& \text { Dollar per Yen } \\
& \text { (.00013) (.00012) } \\
& \Delta_{t}=.0008+\underset{(.0050)}{.0066 D U M S_{t}-} \underset{(.0048)}{.0044 D U D_{t}+u_{t}} \\
& \sigma^{2}{ }_{t}=.00001-.0095 u_{t-1}^{2}+.9383 \sigma_{t-1}^{2}+.00012 D U M S_{t}+.00008 D U M D_{t} \\
& (.00005)^{*} \quad(.00003) * \\
& \Delta_{t}=-.0031+\underset{(.0084)}{.0105 D U M S_{t}}+\underset{(.0076)}{.0093 D U M D_{t}+u_{t}} \\
& \sigma^{2}{ }_{t}=.0006+.1245 u_{t-1}^{2}+.7605 \sigma_{t-1}^{2}-.00017 D U M S_{t}-.00044 D U M D_{t} \\
& \text { (.0003) } \quad(.00029) * * * \\
& \Delta_{t}=-.1045-.0153 \text { DUMS }_{t}-.0844 D U M D_{t}+u_{t} \\
& \text { (.0344) } \quad(.0371)^{*} \\
& \sigma_{t}^{2}=.0049+.0082 u_{t-1}^{2}-.1245 \sigma_{t-1}^{2}+.028796 D U M S_{t}+.03240 D U M D_{t} \\
& (.0142) * \quad(.01493) *
\end{aligned}
$$




\section{Table 7}

\section{Asset Prices During German Current Account Adjustment Regimes}

DM Index

$$
\begin{aligned}
& \Delta_{t}=.0021-.0013 D U M S_{t}-.0012 D U M D_{t}+u_{t} \\
& \text { (.0014) (.0012) } \\
& \sigma^{2}{ }_{t}=.00002+.0886 u_{t-1}^{2}+.1619 \sigma^{2}{ }_{t-1}+\underset{.00001 D U M S_{t}}{.00001)}+.00003 D U M D_{t} \\
& \text { Dollar per DM } \\
& \Delta_{t}=-.0058-.0013 D U M S_{t}-.0082 D U M D_{t}+u_{t} \\
& \sigma_{t}^{2}=.00127+.0921 u_{t-1}^{2}-.2801 \sigma_{t-1}^{2}-.00004 D U M S_{t}+.00008 D U M D_{t} \\
& \text { (.0004) (.00031) }
\end{aligned}
$$

Equity Prices

$$
\begin{aligned}
& \Delta_{t}=.0037-.0025 \text { DUMS }_{t}+.0053 \text { DUMD }_{t}+u_{t} \\
& \text { (.0144) (.0102) } \\
& \sigma^{2}{ }_{t}=.0015+.0726 u_{t-1}^{2}+.7386 \sigma^{2}{ }_{t-1}-.00026 D U M S_{t}-.00115 D U M D_{t} \\
& \text { (.0006) } \quad(.00051)^{*} \\
& \text { Long Term Interest Differentials } \\
& \text { 1979:1 - 1990:12 } \\
& \begin{array}{cc}
\Delta_{t}=-.0129-.0282 D U M S_{t}- & .2147 D U M D_{t}+u_{t} \\
(.0481) & (.0541)^{*}
\end{array} \\
& \sigma^{2}{ }_{t}=.0242+.2351 u_{t-1}^{2}-.0644 \sigma_{t-1}^{2}+.01303 D U M S_{t}+.03635 D U M D_{t} \\
& \text { (.0122) } \quad(.02499)^{* * * *} \\
& \text { 1991:1-1998:12 } \\
& \Delta_{t}=.0074-.0619 D U M S_{t}-.0358 D U M D_{t}+u_{t} \\
& \text { (.0927) } \quad(.0247) * * * \\
& \sigma^{2}{ }_{t}=-.0001+.0804 u_{t-1}^{2}+.7183 \sigma^{2}{ }_{t-1}+.01583 D U M S_{t}+.00455 D U M D_{t} \\
& \text { (.0152) (.00294)*** }
\end{aligned}
$$


Table 8

Asset Prices During UK Current Account Adjustment Regimes

$$
\begin{aligned}
& \text { Pound Index } \\
& \Delta_{t}=-.0013+.0012 D U M S_{t}+.0019 D U M D_{t}+u_{t} \\
& \sigma^{2}{ }_{t}=.00011+.2775 u_{t-1}^{2}+.5646 \sigma^{2}{ }_{t-1}-.00007 D U M S_{t}-.00008 D U M D_{t} \\
& \text { Dollar per Pound } \\
& \Delta_{t}=.0049-.0093 D_{U M S}-.0035 D U M D_{t}+u_{t} \\
& (.0044) * \quad(.0045) \\
& \sigma^{2}{ }_{t}=.00024+.1959 u_{t-1}^{2}+.5747 \sigma_{t-1}^{2}-.00004 D U M S_{t}+.00001 D^{2} U M D_{t} \\
& \text { (.0001) (.0001) } \\
& \Delta_{t}=-.0006+\underset{(.0082)^{*}}{.0185 \operatorname{DUMS}_{t}+} \begin{array}{c}
.0048 D U M D_{t}+u_{t} \\
(.0081)
\end{array} \\
& \sigma^{2}{ }_{t}=.0040+.0224 u_{t-1}^{2}-.8964 \sigma_{t-1}^{2}-.00084 D U M S_{t}+.00091 D U M D_{t}
\end{aligned}
$$

Long Term Interest Differentials

$$
\begin{gathered}
\Delta_{t}=.0312+\underset{(.032)}{.0073 D U M S_{t}+} \begin{array}{c}
.0177 D U M D_{t}+u_{t} \\
(.028)
\end{array} \\
\sigma_{t}^{2}=.00037+.0461 u_{t-1}^{2}+.9402 \sigma_{t-1}^{2}+\underset{(.0018)}{.0048 D U M S_{t}-.00037 D U M D_{t}}
\end{gathered}
$$


Table 9

Asset Prices During Canada Current Account Adjustment Regimes

$$
\text { CAD Index }
$$

$$
\Delta_{t}=.0002-.0015 D U M S_{t}-.0025 D U M D_{t}+u_{t}
$$$$
\sigma^{2}{ }_{t}=.00004+.1961 u_{t-1}^{2}+.4708 \sigma_{t-1}^{2}-.000002 D U M S_{t}+.000002 D U M D_{t}
$$

US Dollar per Canadian Dollar

$$
\begin{aligned}
& \Delta_{t}=.0003-.0018 D U M S_{t}-.0021 D U M D_{t}+u_{t} \\
& \text { (.0014) (.0018) } \\
& \sigma_{t}^{2}=.00001+.0608 u_{t-1}^{2}+.8727 \sigma_{t-1}^{2}+.00004 D U M S_{t}+.00002 D U M D_{t} \\
& \text { (.00006) (.00005) } \\
& \Delta_{t}=.0051+.0030 D_{U M S}-.0030 D U M D_{t}+u_{t} \\
& \sigma^{2}{ }_{t}=.0007+.0534 u_{t-1}^{2}+.7576 \sigma_{t-1}^{2}-.00041 D U M S_{t}-.00062 D U M D_{t}
\end{aligned}
$$

Long Term Interest Differentials

$$
\begin{gathered}
\Delta_{t}=.1855-\underset{.0429 D U M S_{t}+}{(.0605)}\left(\begin{array}{c}
.0300 D U M D_{t}+u_{t} \\
(.0331)
\end{array}\right. \\
\sigma_{t}^{2}=.0124+.1002 u_{t-1}^{2}+.6336 \sigma_{t-1}^{2}+\underset{.05082 D U M S_{t}+.00013 D U M D_{t}}{(.0033) * * *}
\end{gathered}
$$


Table 10

Asset Prices Before and During US Current Account Adjustment Regimes

$$
\begin{aligned}
& \text { US Dollar Index } \\
& \Delta_{t}=.0006-.0064 D U M B D_{t}+u_{t} \\
& \sigma_{t}^{2}=.00012-.05 u_{t-1}^{2}+.7083 \sigma_{t-1}^{2}-.00006 D U M B S_{t} \\
& \text { Equity Prices } \\
& \begin{aligned}
\Delta_{t}=.0115- & .0131 D U M D_{t}+u_{t} \\
& (.0087)^{* * *}
\end{aligned} \\
& \sigma_{t}^{2}=.0015+.0058 u_{t-1}^{2}+.1106 \sigma_{t-1}^{2}-.0007 D U M B S_{t}+.0019 D U M D_{t} \\
& (.0003) * \quad(.00097) * \\
& \Delta_{t}=-.0020+.0384 D U M B S_{t} \\
& \text { (.0194)* } \\
& \sigma_{t}^{2}=.0003+.0241 u_{t-1}^{2}+.9418 \sigma_{t-1}^{2}
\end{aligned}
$$


Table 11

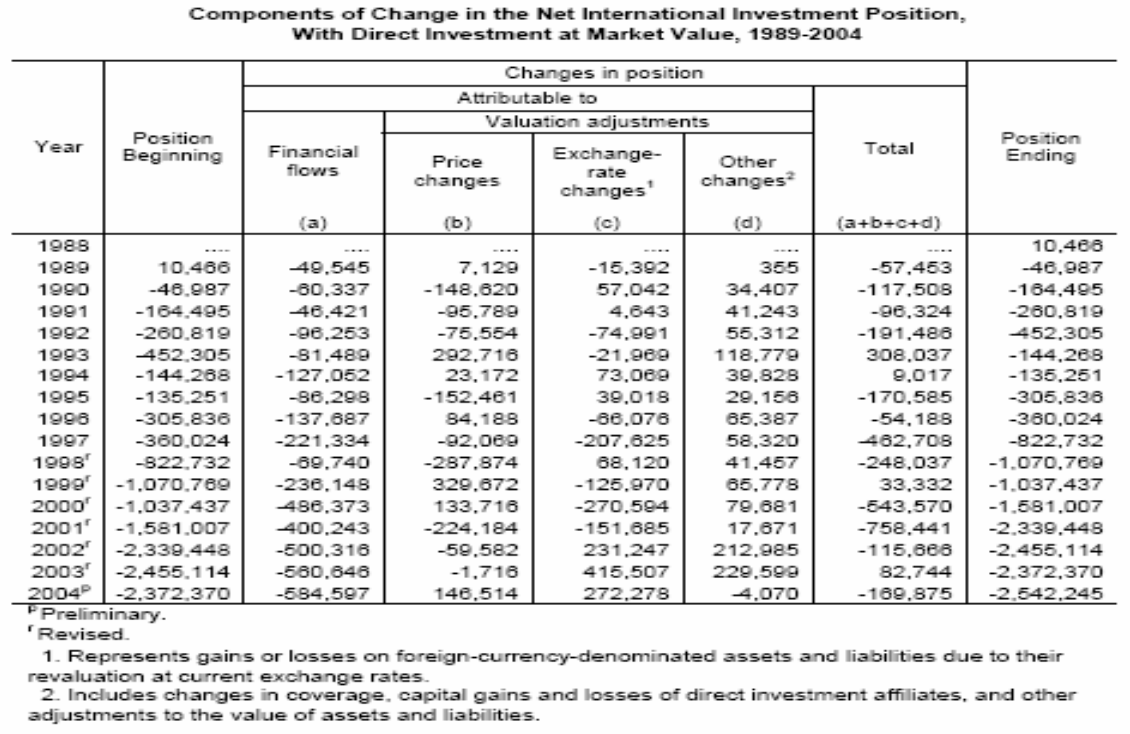


Table 12

\begin{tabular}{|c|c|c|c|c|c|c|c|c|c|c|}
\hline & 1989 & 1995 & 1997 & 1998 & 1999 & 2000 & 2001 & 2002 & 2003 & 2004 \\
\hline \multicolumn{11}{|l|}{ US owned assets abroad } \\
\hline$\overline{\text { Total Assets }}$ & $2,350,2353$ & $3,964,558$ & $5,379,128$ & $6,174,518$ & $7,390,427$ & $7,393,643$ & $6,898,707$ & $6,613,320$ & $7,863,968$ & \\
\hline US Private Assets & $2,094,878$ & $3,703,433$ & $5,158,094$ & $5,941,744$ & $7,169,782$ & $7,180,075$ & $6,683,092$ & $6,369,409$ & $7,595,619$ & \\
\hline FDI Assets & 832,460 & $1,363,792$ & $1,879,285$ & $2,279,601$ & $2,839,639$ & $2,694,014$ & $2,314,934$ & $2,039,780$ & $2,730,289$ & \\
\hline Foreign Securities & 314,294 & $1,203,925$ & $1,751,183$ & $2,052,995$ & $2,525,341$ & $2,385,353$ & $2,114,734$ & $1,846,879$ & $2,474,374$ & \\
\hline \multicolumn{11}{|l|}{ Income Receipts } \\
\hline Total Receipts & 160270 & 208065 & 254534 & 258871 & 290474 & 347614 & 283761 & 263861 & 291354 & 365886 \\
\hline FDI Receipts & 61981 & 95260 & 115323 & 103963 & 131626 & 151839 & 128665 & 147291 & 187522 & 237564 \\
\hline \multicolumn{11}{|c|}{ Returns on US owned assets abroad } \\
\hline Return on all Assets & $8.0 \%$ & $6.3 \%$ & $5.5 \%$ & $4.8 \%$ & $4.7 \%$ & $4.7 \%$ & $3.8 \%$ & $3.8 \%$ & $4.4 \%$ & $4.7 \%$ \\
\hline Return on FDI & $9.0 \%$ & $8.5 \%$ & $7.2 \%$ & $5.5 \%$ & $5.8 \%$ & $5.3 \%$ & $4.8 \%$ & $6.4 \%$ & $9.2 \%$ & $8.7 \%$ \\
\hline Return on non-FDI assets & $7.5 \%$ & $5.1 \%$ & $4.6 \%$ & $4.4 \%$ & $4.1 \%$ & $4.3 \%$ & $3.3 \%$ & $2.5 \%$ & $2.3 \%$ & $2.5 \%$ \\
\hline \multicolumn{11}{|l|}{ Foreign-owned assets in the US } \\
\hline Total Liabilities & $2,397,222$ & $4,270,394$ & $6,201,860$ & $7,249,895$ & $8,437,115$ & $8,982,199$ & $9,206,868$ & $9,166,727$ & $10,514,958$ & \\
\hline Liabilities to Private Foreigners & $2,055,476$ & $3,587,521$ & $5,328,144$ & $6,353,721$ & $7,486,027$ & $7,951,491$ & $8,124,572$ & $7,954,004$ & $9,040,797$ & \\
\hline FDI Liabilities & 534,734 & $1,005,726$ & $1,637,408$ & $2,179,035$ & $2,798,193$ & $2,783,235$ & $2,560,294$ & $2,025,345$ & $2,435,539$ & \\
\hline Securities and Currency (Cash, US & 716,523 & $1,466,328$ & $2,262,490$ & $2,675,016$ & $3,042,633$ & $3,260,616$ & $3,459,610$ & $3,545,585$ & $4,251,500$ & \\
\hline Other Liabilities to Private Foreigne & 804,219 & $1,115,467$ & $1,428,246$ & $1,499,670$ & $1,645,201$ & $1,907,640$ & $2,104,668$ & $2,383,074$ & $2,353,758$ & \\
\hline \multicolumn{11}{|c|}{ Income Receipts } \\
\hline Total Payments & -141463 & -189353 & -244195 & -257554 & -280037 & -329864 & -263120 & -259626 & -261106 & -344925 \\
\hline FDI Payments & -7045 & -30318 & -42950 & -38418 & -53437 & -56910 & -12783 & -46460 & -68657 & -105252 \\
\hline \multicolumn{11}{|c|}{ Returns on US owned assets abroad } \\
\hline Return on all Liabilities & $7.1 \%$ & $5.5 \%$ & $4.9 \%$ & $4.2 \%$ & $3.9 \%$ & $3.9 \%$ & $2.9 \%$ & $2.8 \%$ & $2.8 \%$ & $3.3 \%$ \\
\hline Return on FDI & $1.8 \%$ & $4.0 \%$ & $3.5 \%$ & $2.3 \%$ & $2.5 \%$ & $2.0 \%$ & $0.5 \%$ & $1.8 \%$ & $3.4 \%$ & $4.3 \%$ \\
\hline Return on non-FDI Liabilities & $8.4 \%$ & $5.9 \%$ & $5.3 \%$ & $4.8 \%$ & $4.5 \%$ & $4.8 \%$ & $4.0 \%$ & $3.2 \%$ & $2.7 \%$ & $3.0 \%$ \\
\hline \multicolumn{11}{|l|}{ Return Differentials } \\
\hline Total & $0.9 \%$ & $0.8 \%$ & $0.6 \%$ & $0.7 \%$ & $0.8 \%$ & $0.8 \%$ & $0.9 \%$ & $1.0 \%$ & $1.6 \%$ & $1.4 \%$ \\
\hline FDI & $7.2 \%$ & $4.5 \%$ & $3.7 \%$ & $3.2 \%$ & $3.3 \%$ & $3.3 \%$ & $4.3 \%$ & $4.5 \%$ & $5.8 \%$ & $4.4 \%$ \\
\hline Non-FDI & $-0.9 \%$ & $-0.8 \%$ & $-0.7 \%$ & $-0.4 \%$ & $-0.4 \%$ & $-0.5 \%$ & $-0.7 \%$ & $-0.7 \%$ & $-0.4 \%$ & $-0.5 \%$ \\
\hline
\end{tabular}


Figure 1

US real broad trade weighted dollar index

(\% decline from February 1985 to November 1988 vs February 2002 to November 2005)

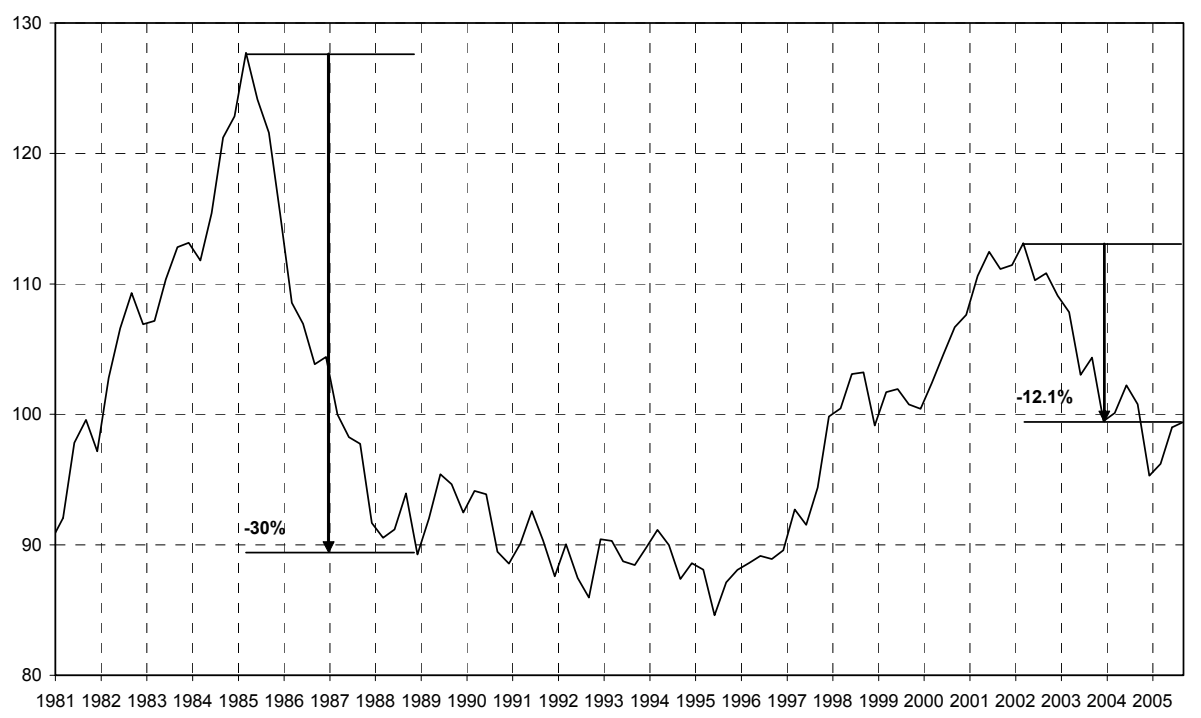


Table 13

\begin{tabular}{|c|c|c|c|c|c|c|c|c|c|}
\hline & 1989 & 1995 & 1997 & 1998 & 1999 & 2000 & 2001 & 2002 & 2003 \\
\hline \multicolumn{10}{|l|}{ Portfolio Shares } \\
\hline \multicolumn{10}{|c|}{ Private US Investment Abroad } \\
\hline FDI & $39.7 \%$ & $36.8 \%$ & $36.4 \%$ & $38.4 \%$ & $39.6 \%$ & $37.5 \%$ & $34.6 \%$ & $32.0 \%$ & $35.9 \%$ \\
\hline Securities and Currency & $15.0 \%$ & $32.5 \%$ & $34.0 \%$ & $34.6 \%$ & $35.2 \%$ & $33.2 \%$ & $31.6 \%$ & $29.0 \%$ & $32.6 \%$ \\
\hline Other Private Assets & $45.3 \%$ & $30.7 \%$ & $29.6 \%$ & $27.1 \%$ & $25.2 \%$ & $29.3 \%$ & $33.7 \%$ & $39.0 \%$ & $31.5 \%$ \\
\hline \multicolumn{10}{|c|}{ Private Foreign Investment in the US } \\
\hline $\mathrm{FDI}$ & $26.0 \%$ & $28.0 \%$ & $30.7 \%$ & $34.3 \%$ & $37.4 \%$ & $35.0 \%$ & $31.5 \%$ & $25.5 \%$ & $26.9 \%$ \\
\hline Securities and Currency & $34.9 \%$ & $40.9 \%$ & $42.5 \%$ & $42.1 \%$ & $40.6 \%$ & $41.0 \%$ & $42.6 \%$ & $44.6 \%$ & $47.0 \%$ \\
\hline Other Private Assets & $39.1 \%$ & $31.1 \%$ & $26.8 \%$ & $23.6 \%$ & $22.0 \%$ & $24.0 \%$ & $25.9 \%$ & $30.0 \%$ & $26.0 \%$ \\
\hline
\end{tabular}

